\title{
AGAMA DAN KEADABAN PUBLIK
}

\author{
Mahrus As'ad \\ STAIN Jurai Siwo Metro \\ Email: mahrusasad@yahoo.co.id
}

\begin{abstract}
Operationalization of religion in a civilized community life in inter-relationship between religion mengkait complex itself on the one band with the various elements of culture and society in wbich individuals reside and live on the other. Complexity of the relationship of religion can not be made freely as it should meet the demands of te sching. Elements of local cultural values are prominent, such as live view of the strong regional / ethnic, social control and law enforcement are weak, an easy rule is violated, the authority (authorities) that the state continues to decline, to name a few, is a major barrier to religion in the running his sacred mission to its full potential in society. Culture of civilized life can not be realized in the concrete life just by rebying on faith alone, but also need the willingness of all parties, including state officials, to subjugate himself under the control of the values and norms that exist and run it with full sincerity.
\end{abstract}

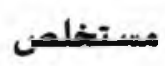

تفعيل الدين في حياة المجتمع المتحضبزفي العلاقة المعتدة يين الدين وتعلق ذفهبها من جهة مع مهتلف عناصر الثقافة والمجتهع الذي يقيم الأفراد والعيش من جهة أخرى .لا يمكن أن تعقد العلاقة بين الدين تتم بحرية كما يجب ان تلبي مطالب التدربس .عناصر من القيم الثقافية

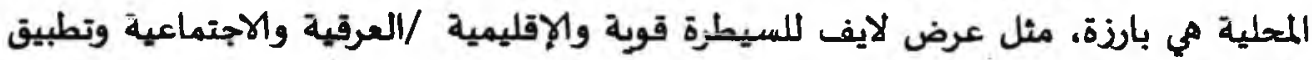
القانون ضعيفة: وخرق لقاعدة سهلة، والس.طلة) السلطات (أن الدولة مســهرة في التناقص، على سبيل المثال لا الحصر، يشكل عائقا رئيسيا للدين في تشغيل له المهمة المةدمعة لإمكاناتها الكامله في المجتمع .لا يمكن أن ثقافة الحياة المتحضرة أن تتحقق في الحياة المالهوسة فقطا من خلال الوعتماد على الايمان وحده، ولكن تحتاج أيضا المل استعداد جميع الأطراف، بما في ذلك المسؤولين في الدولة، لإخضاع نفسه تحت سنيطرة القيم والمعايير الموجودة وتشغيلها مع الاخلاص الكامل. 
Keywords: Agama, Keadaban Publik, Kebudayaan, Islam, Moralitas

\section{A. Pendahuluan}

Keberadaan bangsa Indonesia tidak dapat dipisahkan dengan agama. ${ }^{1}$ Kemana saja kita pergi mudah sekali kita temukan tempat-tempat peribadatan (mesjid, gereja, klenteng, pura), yang selalu ramai dengan jamaah, lebih-lebih saat kebaktian umum. Peringatan hari-hari besar dan festival keagamaan, diselenggarakan baik oleh masyarakat maupun pemerintah, tidak pernah sepi dari pengunjung. Masyarakat dengan mudah mendapatkan kuliah agama, dalam bentuk pengajian umum, menghadirkan para penceramah kondang, didampingi para artis, pelawak, dan pejabat negara. Lembaga-lembaga pendidikan agama, baik negeri maupun swasta, sudah lama beroperasi dan telah menghasilkan banyak lulusannya, dan tidak sedikit dari mereka telah menjadi orang-orang penting di negeri ini. Belakangan semakin banyak orang terlihat berlalu-lalang berpakaian beratribut agama di tempat-tempat umum, seperti di pasat-pasar, kantor-kantor pemerintah, kampus-kampus, dan bahkan tempat-tempat rekreasi. Begitu pentingnya peran agama, hampir-hampir tidak ada bagian hidup dari bangsa ini yang tidak dikaitkan dengan agama.

Bermodalkan religirsitas seperti ini, sangat wajar kalau kita kemudian berharap bangsa Indonesia bisa menjadi contoh bagi munculnya corak kehidupan bangsa yang lebih beradab, yaitu suatu kondisi kehidupan yang secara integratif senantiasa dijiwai oleh dan berpegang teguh pada serta menjunjung tinggi nilai-nilai etika moral, baik secara sendiri- sendiri maupun kolektif. Hidup berkeadaban dimaksud tidak hanya mengacu pada kehidupan orang-perorang, tetapi juga masyarakat luas, termasuk para penyelenggara negara, terkait hal-hal berdimensi politik, sosial, ekonomi, hukum, dan sebagainya. ${ }^{2}$ Hidup berkeadaban meniscayakan adanya kesediaan individu atau kelompok untuk berinteraksi dengan individu/kelompok lain dalam usaha

\footnotetext{
1 A. Mukti ali, Beberapa Persoalan Agama Dewasa Ini, (Jakarta: Rajawali Press, 1981) hal. 208-209.

2 Bakhtiat Effendy, "Wawasan Al-Qur'an tentang Masyarakat Madani Menuju Terbentuknya Negara-Bangsa yang Modem", Paramadina, Vol. I No. 2 (1999), hal. 77.
} 
pemenuhan berbagai kebutuhan hidup secara manusiawi, dibedakan dengan cara-cara biologis dan sosial hewan. Di sini, yang menjadi dasar pijakannya adalah dimensi etis-moral, dan agama tak disangsikan lagi merupakan salah satu sumber utamanya.

Sejujurnya, realitas masyarakat kita dalam menjalani kehidupan sehari-hari pada umumnya belum menunjukkan kecocokan antara ekspresi dan penggunaan simbol-simbol keagamaan yang diperlihatkan di depan publik dengan nilai-nilai dan norma etika-moral yang harus dijunjung tinggi. Yang sering kali kita saksikan justru betbagai anomali dalam bentuk pelanggaran susila dan sosial, mulai dari tawaran pelajar, perkelahian antar kelompok/warga, pemerkosaan di kendaraan umum, penjarahan dan anarkisme, intoleransi kepada pihak di luar kelompoknya, suka melanggar hukum dan menyalahgunaan kekuasaan, motal hipokrit, hingga kotupsi, untuk menyebutkan beberapa. Sangat ironis bagi masyarakat bangsa yang sejak dulu dikenal "religius". Muncul pertanyaan, sejauh mana agama sebagai sebagai modal budaya berpengaruh terhadap pembentukan moralitas bangsa? Bagaimana aturan-aturan agama seharusnya beroperasi, agar mampu memberikan arah bagi tervujudnya kehidupan secara berkeadaban dalam realitas masyarakat pemeluknya?

Tidak mudah memberikan jawaban untuk kedua pertanyaan ini. Hanya saja yang jelas, masih sangat banyak orang berharap bahwa agama bisa memberikan penyelesaian terhadap berbagai problem moral di masyarakat, meskipun jebenarnya agak berlebihan. Seperti diketahui, agama memang mengandung arti keterikatan dan ketundukkan manusia dengan Tuhannya, melalui seperangkat ijaran yang harus diikuti demi terwujudnya kehidupan yang benar dan lebih jaik. ${ }^{3}$ Agama juga merupakan unsur pokok dalam pembentukan motivasi dan ?ola perilaku, sehingga menyebabkan para pemeluknya mau bertindak secara ietasi dengan ajaran Kitab Suci. Namun, dalam operasionalnya pada kehidupan syata, ketentuan-ketuan yang diharuskan Kitab Suci tidak selalu serkorespondensi secara kongruens dengan perilaku para pemeluknya di

Harun Nasution, Isham Ditinjau dari Berbagai Aspeknya, (Jakarta: UI Press, 1985) Jilid I, hal. 10. 
masyarakat. Artinya bahwa apa yang ditentukan agama tidak dengan sendirinya ditaati dan diikuti oleh para pemeluknya secara konsekuen dalam realitas kehidupan konkret pada masyarakat pemeluknya, karena adanya faktor-faktor lain, yang turut menentukan. ${ }^{5}$

\section{B. Posisi Agama dalam Kebudayaan Kita}

Untuk menjawab pertanyaan pertama, perlu terlebih dahulu dipahami posisi agama dalam kebudayaan kita. Kebudayaan, menurut Parsudi Suparlan, didefinisikan sebagai keseluruhan pengetahuan dan keyakinan-keyakinan yang digunakan sebagai pedoman oleh para pendukungnya untuk memahami dan menginterpretasi dan digunakan sebagai referensi atau pedoman bertindak sesuai dengan lingkungan yang dihadapi. Sebagi pedoman menyeluruh bagi. kehidupan manusia, kebudayaan berisikan konsep-konsep, teori-teori, dan metode-metode atau petunjuk-petunjuk agar dapat digunakan manusia secara operasional untuk memenuhi hampir semua kebutuhannya dalam menghadapi dunia nyata agar dapat hidup lebih baik lagi secara biologi, sosial, dan adab integratif. ${ }^{6}$

Kebudayaan kita dikenal sangat majemuk, yang secara garis besarnya dapat dikelompokkan ke dalam tiga jenis: kebudayaan nasional, kebudayaan suku bangsa, dan kebudayaan umum-lokal. Kebudayaan nasional berfungsi dan operasional kegunaannya dalam suasana-suasana nasional dan arena-arena interaksi yang terwujud dalam struktur dan pranata-pranata sosial yang diciptakan. Kebudayaan suku bangsa berfungsi dan operasional kegunaannya dalam suasana-suasana suku bangsa dan arena-arena interaksi yang ada dalam struktur dan pranata-pranata sosial yang terwujud dari kebudayaan suku bangsa dan menjadi unsur pendukung bagi kelestariannya. Kebudayaan umum-lokal berfungsi dan operasional kegunaannya dalam berbagai faset kehidupan umum (ekonomi, politik, sosial, dan emosional) yang betlaku dalam lokal-lokal atau

\footnotetext{
4 Bassam Tibi, Islam Kebudayaan dan Perubaban Sosial, (Yogyakarta: Tiara Wacana, 1999) hal. 19.

5 Taufik Abdullah, Islam dan Masyarakat Pantulan Sejarab Indonesia, (Jakarta: LP3ES, 1996) hal. 231.

6 Parsudi Suparlan, "Kebudayaan dan Pembangunan", IKA, No. 11 Tahun XIV, 1986.
} 
daerah setempat. Kedudukan dan kegunaannya sama dengan lingua franca dalam bahasa, arena-arena kegiatan kebudayaan umum-lokal berada di luar kegiatan operasional dari kebudayaan nasional maupun kebudayaan suku bangsa, walaupun mungkin secara fisik tempat dari arena kegiatan kebudayaan umum lokal itu sama tempatnya dengan tempat bagi arena-arena kegiatan kedua jenis kebudayaan sebelumnya. Dalam konteks kebudayaan daerah, kebudayaan suku bangsa dan kebudayaan umum lokal, merupakan unsur-unsur dari kebudayaan daerah, yang berbeda dengan kebudayaan nasional. ${ }^{7}$

Keanekaragaman kebudayaan masyarakat kita tidak hanya bersifat horizontal, tetapi juga vertikal, mulai dari yang berkebudayaan sederhana, lebih kompleks, semakin kompleks dan sangat kompleks. ${ }^{8}$ Keanekaragaman kebudayaan ini dengan sendirinya menyebabkan munculnya beraneka ragamnya kebutuhan warganya yang harus dipenuhi, secara sendiri-sendiri maupun kolektif, yang pada gilirannya akan mendorong terwujudnya berbagai model pengetahuan sebagai pedoman hidup yang berguna dan relevan untuk usaha pemenuhan kebutuhan tersebut. Dalam menghadapi semua kebutuhan itu, agama hanya mencakup serta terpusat pada pemenuhan kebutuhan yang sifatnya adab integratif saja, bersama dengan unsur kebudayaan lainnya seperti ilmu pengetahuan-teknologi, hukum, dan seni, yang muncul dari hakekat manusia sebagai makhluk pemikir-bermoral. Jadi, agama dalam hubungan dengan kebudayaan, berfungsi sebagai pedoman etis-morai dalam wujud nilainilai budaya, yang mengintegrasikan dan menjiwai tiap upaya pemenuhan kebutuhan manusia, sehingga menjadi beradab, dalam arti dipenuhi dengan ciriciri kemanusiaan, dibedakan dari cara-cara pemenuhan kebutuhan-kebutuhan biologi dan sosial hewan. Singkatnya, manusia dalam usaha memenuhi kebutuhan budayanya memerlukan pedoman agama untuk menjadikan dirinya sebagai manusia.

\footnotetext{
'Parsudi Supatlan, "Pendidikan Budaya Manusia Indonesia", dalam Sudjangi (ed.) Kajian Agama lan Masyarakat, (Jakarta: Balitbang Agama Depag RI, 1992/1993) Jilid III, hal: 184.

'Ibid, hal. 185.

'Parsudi Suparlan, 1986. Op. cit.
} 
Kebudayaan sebagai pedoman hidup masyarakat dimungkinkan mengalami perubahan, tergantung pada kekuatan nilai-nilai budaya yang menopangnya. Bila nilai-nilai budaya yang menjadi penopang (asas) kebudayaan itu sumbernya ajaran agama, sulit bagi kebudayaan tersebut mengalami perubahan, karena nilai-nilai budaya tersebut sudah menjadi sakral atau suci. ${ }^{10}$ Sistem nilai-nilai budaya adalah ide-ide yang mengkonsepsikan hal-hal paling bernilai, yang di dalamnya berisi keyakinan-keyakinan mengenai kebenaran, yang berfungsi sebagai pedoman penilaian tertinggi bagi kelakuan manusia secara budaya dari warga masyarakat bersangkutan." Mempertahankan nilai-nilai budaya yang sakral atau suci dianggap sama dengan mempertahankan agama itti sendiri. Kekuatan dan daya tahan kebudayaan sebagai pedoman hidup sangat tergantung pada agama.

Namun, perlu dipahami bahwa dimaksud agama dalam konteks ini adalah agama dalam pengertian antropologis, yaitu sebagai pengetahuan yang menjadi dasar keyakinan, yang hidup di masyarakat, dan bukannya yang terwujud sebagai petunjuk-petunjuk Tuhan yang ada dalam Kitab Suci. Jika agama yang terdapat dalam Kitab Suci sifatnya universal, pengetahuan dan pemahạman serta keyakinan agama yang hidup di masyarakat bersifat lokal, disesuaikan dengan kondisi, sejarah, lingkungan hidup, dan kebudayaan masyarakat bersangkutan. ${ }^{12}$ Mengapa? Karena untuk menjadi seperti itu, agama harus melakukan berbagai proses perjuangan dalam upaya meniadakan nilai-nilai budaya yang bertentangan dengan miliknya sendiri, di samping harus pula melakukan berbagai penyesuaian dengan nilai-nilai budaya dari masyarakat bersangkutan, sehingga dapat diterima dan diyakini kebenarannya. Jadi, watak lokal suatu agama sesungguhnya hal biasa dalam suatu masyarakat, dalam arti tidak bisa

\footnotetext{
10 Parsudi Suparlan, "Penelitian Agama Islam: Tunjauan Disiplin Antropologi", dalam Mastuhu dan Deden Ridwan, Tradisi Baru Penelitian Agama Islam Tinjauan Antar Disiplin, (Bandung Nuansa, 1998) hal 113.

${ }^{11}$ Koentiaraningrat, Kebudayaan Mentafitas dan Pembangunan, (Jakarta: Gramedia, 1993) hal. 25

12 Parsudi Suparlan, "Penelitian Agama Islam: Tunjauan Disiplin Antropologi", dalam Mastuhu dan Deden Ridwan, Tradisi Baru Penelition Agama Islam Tinjauan Antar Disiplin, (Bandung Nuansa, 1998) hal. 114.
} 
dihindari, agar ia bisa diterima dan dipedomani oleh warganya sebagai landasan etik-moral yang selaras dan sesuai dengan karakteristik mereka.

Terjadinya lokalisasi agama adalah keniscayaan dan hal ini sekaligus menunjukkan bahwa tidak pernah ada keseragaman dalam keberagamaan masyarakat ${ }^{13}$ Hal yang sama juga terjadi pada pemahaman masyarakat terhadap Kitab Suci. Itulah sebabnya, sulit diperoleh terjadinya korespondensi secara kongruens antara agama seperti dikehendaki Kitab Suci dengan "agama-agama lokal", atara sebut saja "agama teoritis" dengan "agama praktis" di masyarakat, karena hadimya berbagai ragam tafsir (interpreatsi) yang mengantarai keduanya. Pemahaman dan pengetahuan dari tafsir-tafsir yang beragam itulah yang secara sosio-antropologis dipegangi dan dipedomani para pemeluk agama, bukan "agama teoritis" yang ada di Kitab Suci, yang sesungguhnya telah mempengaruhi alam pikitan dan perilaku mereka dalam kehidupan konkrit. Inilah yang kemudian menghasilkan cara-cara beragama dalam masyarakat, yang bisa berbeda antara yang satu dengan lainnya, tergantung kebutuhan mereka beragama. $^{14}$

${ }^{13}$ QS Al-Maidah [5]: 48.

14 Terkait cara-cara beragama masyarakat, meminjam kategorisasi Dale Cannon, secara umum dapat dikelompokkan ke dalam enam macam cara beragama dengan orientasinya masingmasing: pertama, cara ritus (upacara) suci, seperti ditunjukkan namanya, memusatkan diri pada kegiatan ritual dalam berbagai bentuknya dengan tujuan utamanya mengadakan pendekatan diri dan menjalin hubungan yang tepat dengan Tuhan. Kedua, cara perbuatan benar, berorientasi terwujudnya ketentuan-ketentuan agama demi terwujudnya "tertib ilahi" di bumi. Ketiga, cara ketaatan, bertujuan menjalin hubungan yang benar dengan Tuhan, dengan permusatan diri pada ketaatan batiniah, melalui pemujan dan pemeliharaan sikap-sikap khusus menuju manifestasi bubungan dengan Tuhan, tanpa mementingkan aspek ritual-moral lahiriah. Keempat, cara mediasi samanik, sebagai usaha menghadapi berbagai musibah dan bencana, didasari keyakinan bahwa sumber-sumber "supematural" atau dunia spinit dapat digunakan mengatasi kejadian itu, melaui mediasi seorang saman (dukun), sebagai kendaraan mendekati Tuhan, dalam rangka mencapai penyembuhan dan kesejahteraan hidup masyarakat. Kelima, cara pencarian mistik, yaitu usaha sadar melalui disiplin asketik-meditatif demi tercapainya kesatuan dengan Realitas Mutlak Fokusnya bukan pada hasil akhirnya, melainkan pada upaya pencarian makna hidup sesungguhnya di lingkungan monastik atau dengan bertapa. Dan keenam, cara pengetahuan diarahkan pada usaha memahami realitas agama melalui studi kritis-rasional berdimensi ibadat, bertujuan memperoleh kebenaran bukan sekedar kebenarana dalam arti "jawaban-jawaban benar dan tepat", melainkan pengetahuan kebijaksanaan ilahi, bersifat teoritis-prraktis. Dale Cannon, Enam Cara Beragama, Penerjemah Djam'annuri, (Jakarta: Dipertais Depag RI, 2002) hal. 48-74. 
Beraneka ragamnya cara beragama dari agama-agama yang hidup di dan menghidupi masyarakat, mulai dari agama-agama formal, yang biasanya mereka mentolelir adanya banyak aliran dan paham keagamaan, hingga agama-agama antropologis, menjadikan peta keberagamaan masyarakat kita semakin kompleks dan rumit. Tumpang tindih biasa terjadi, karena keberagamaan atau cara keberagamaan seseorang atau kelompok partisipan tertentu tidak bisa mengikuti tradisi mereka sendiri secara ketat dan eksklusif. Bahkan sangat dimungkinkan terjadinya "pinjam-meminjam" berbagai unsur yang dipandang perlu di antara mereka. Namun, apapun cara beragama yang ada, secara teoritis, dapat mendatangkan kebaikan dan keutamaan bagi partisipannya masingmasing, sering diistilahkan dengan hikmah, dengan syarat dijalankan secara konsisten dan sesuai dengan tujuan utamanya. Tetapi jika gagal, sebagai gantinya, yang muncul berbagai bentuk penyimpangan yang justru akan memperlihatkan sisi-sisi keburukan masing-masing, yang bisa disalah-gunakan untuk tujuan-tujuan tersembunyi dan egoistik.

Bagaimana dengan "produk" keberagamaan masyarakat kita? Dari gejalagelaja yang tampak, kiranya tidak sulit bagi kita untuk berkesimpulan bahwa sesungguhnya telah terjadi berbagai penyimpangan beragama, di samping pada taraf tertentu terdapat "keberhasilan" relatif, dari cara-cara beragama pada sebagian besar masyarakat kita. Akan panjang daftarnya bila disebutkan indikatornya satu persatu. Seperti bisa kita saksikan di siaran televisi, kecenderungan mengangkat ritus-ritus atau festival-festival keagamaan lama semata-mata demi ritus atau festival keagamaan itu sendiri, formalisasi dan penonjolan simbol-simbol agama di ranah publik, kesalehan eskapistik diperlihatkan sebagian kalangan karena tidak tahan menghadapi maraknya kemungkaran sosial, hipokrasi moral dalam skala massif, untuk menjebut beberapa, merupakan gejala penyimpangan paling nyata dari praktek keberagamaan masyarakat kita dewasa ini. Seperti sudah disebut di muka, anomali telah terjadi hampir dalam keseluruhan kehidupan beragama masyatakat kita. Sangat ironis. Secara formal memang terlihat munculnya gejala kesemarakan dan kegairahan dalam kehidupan beragama masyarakat, mulai dari level bawah hingga kalangan atas, termasuk di kaloangan penyelenggara negara. 
Berbagai macam simbol keberagamaan sangat mudah bisa kita jumpai di mana saja, bahkan di tempat-tempat yang kurang tepat. Namun, pada saat yang bersamaan, berbagai bentuk pelanggaran etika-moral di masyarakat terjadi dan terus terjadi, seolah tanpa kendali. Bagaimana hal ini bisa terjadi?

Kiranya perlu diketahui bahwa penerimaan agama sebagai pedoman hidup bukan bersifat genetika, melainkan melalui warisan sosial, yang disebut pendidikan, baik secara formal maupun tidak formal. Proses ini bersifat menyerap dan mencakup semua aspek kehidupan secara samar-samar dan halus, tetapi pasti, hingga mempengaruhi bentuk-bentuk dan corak-corak kelakuan, sikap dan keyakinan yang amat terinci, yang biasanya terwujud dalam cara-cara berbicara, berpikir, merasakan, dan bertindak. Hanya saja, proses penerimaan ini, walaupun telah diniatkan dan diupayakan sebaik mungkin, dalam pelaksanaannya tidak selalu mulus dan sesuai dengan yạng dicita-citakan. Banyak faktor yang turut mempengaruhi berlangsungnya proses ini; selain kondisi individu bersangkutan, juga faktor-faktor eksternal bersifat ekonomi, politik, sosial, historis, dan budaya.

\section{Agama dan Ketaatan Publik}

Nilai-nilai dan norma-norma agama, tak disangsikan lagi, berfungsi sebagai pengontrol dan pengawas tethadap tindakan seseorang, secara pribadi maupun sosial. Dalam kehidupan sehari-hari, mengapa seseorang atau sekelompok warga masyarakat tidak melakukan perbuatan tertentu hampir bisa dipastikan karena keyakinan agama. Agama menjadi sumber nilai-nilai dan norma paling utama, dan menjadi pedoman dalam bertingkah laku bagi para penganutnya. Perbedaan agama hampir tidak menimbulakan perbedaan penting dalam ajaran moral. Itulah sebabnya, dalam soal moral agama-agama yang berbeda mudah mencapai kesepakatan, tidak seperti dalam aspek akidah, karena yang terakhit ini menyangkut keimanan. ${ }^{15}$

${ }^{15}$ Ada dua jenis ajaran moral yang bersumber dari agama; pertama, aturan etis yang sifatnya detail, seperti larangan makan-minum, kewajiban puasa, ibadat, dan sebagainya, yang bisa berbeda pada agama berlainan; namun, konsekwensinya juga tidak besar, karena menyangkut kalangan internal saja. Kedua, aturan etis lebih umum, yang cakupannya melampaui salah satu agama, seperti larangan mencuri, membunuh, berdusta, dan berzina. Dalam agama Yahudi- 
Pengaruh agama juga besar sekali dalam menentukan kekuatan daya ikat moral. Supaya kewajiban-kewajiban moral benar-benar mengikat, diperlukan Tuhan Yang Maha Hadir (Omnipresent), yang akan mengyanjar siapa saja yang berbuat baik dan menghukum siapa saja yang berbuat jahat. Di dunia orang bisa lolos dari polisi atau hakim manusia, tetapi di akherat kelak tidak pernah ada jalan untuk bisa lolos dari pengadilan Tuhan sebagai Hakim Tertinggi. Begiti pentingnya pengawasan Tuhan, sampai-sampai sastrawan termasyhur Rusia, Dostoyevski pernah berkata, "Kalau saja Tuhan tidak ada, semuanya diperbolehkan". Pandangan tradisional seperti ini selama berabad-abad diterima banyak orang, dan hingga kini juga masih banyak pengikutnya. ${ }^{16}$ Kuatnya ajaran etis-moral di kalangan pemeluk agama tidak lain karena adanya keyakinan mereka bahwa ajaran etis-moral tersebut berasal dari Tuhan, dan diterima berdasarkan alasan keimanan.

Sungguhpun demikian, perlu hati-hati untuk tidak buru-buru berkesimpulan bahwa ada hubungan garis lurus antara sejumlah norma keagamaan tertentu dengan seperangkat tindakan etis tertentu pula. Karena operasionalisasi norma keagamaan tidak selalu dalam hubungan satu-satu dengan tindakannya, melainkan berada dalam kaitan yang rumit dengan perangkat norma keagamaan lainnya. ${ }^{17}$ Dapat dicontohkan, misalnya, tentang penerimaan norma Keluarga Kecil $(\mathrm{KK})$ atau Keluarga Berencana $(\mathrm{KB})$ yang sudah lama diperkenalkan dalam masyarakat. Dari beberapa firman Tuhan terkait dengan norma itu. ${ }^{18}$ kita berkesimpulan bahwa kaum muslim mengetahui agamanya mengajarkan pandangan yang tidak terlalu positif pada keinginan banyak anak. Namun, tidak berarti mereka dengan sendirinya mengikuti dan mempraktekkannya dalam hidup sehari-hari dengan membentuk keluarga kecil.

Kristen aturan-aturan jenis kedua ini terdapat dalam apa yang sebagai cdekalog" atau "sepuluh perintan Tuhan" (the Ten Commandements); dalam agama Islam terdapat dalam Al-Qur'an dan Hadis Nabi, serta kitab-kitab fikib. Karena peraturan jenis kedua ini dianggap paling penting dan penerimaannya oleh semua agama (besar) bampir tidak ada perbedaan, pandangan moral mereka pada dasarnya juga tidak berbeda.

${ }^{16}$ K. Bertens, Etika, Jakarta: Gramedia, 1997) bal 37.

17 Nurcholish Madjid, Masyarakat Religius Memburnikan Nilai-Nilai Islam dalam Kebidupan Masyarakat, (Jakarta: Paramadina, 2000) hall 6.

${ }^{18}$ Misalnya Al-Qur'an Surat Al-Afal (8): 28; Al-Taghabun (64): 14-15; dan Al-Hadid (37): 20. 
Karena ajaran tentang tidak perlunya banyak anak harus berhadapan atau dikompromikan dengan ajaran-ajaran lain yang tidak selalu sejalan dengannya, misalnya dengan ajaran bahwa umat Islam perlu buman resource yang besar untuk menjadi kuat, seperti sering dikhotbahkan oleh beberapa kalangan.

Kehati-hatian yang sama juga diperlukan ketika kita menghadapi hubungan antara norma agama dengan pranata (institusi) keagamaan, atau pranata keagamaan sendiri dengan perilaku keagamaan warganya. Dengan pranata dimaksudkan organ-organ keagamaan yang memberi kerangka bagi terlaksananya berbagai fungsi keagamaan dalam masyarakat, berasal dari kebiasaan beragama orang banyak yang kemudian berkembang secara mantap menjadi norma-norma mapan, dan selanjutnya menjadi aturan-aturan atau prosedur keagamaan tertentu, yang melambangkan kesatuan pandangan mengenai hakekat dan cara mengusahakan kebutuhan-kebutuhan keagaman warganya. Wujudnya bisa bersifat material, seperti masjid, kuil, gereja; bisa juga keorganisasian, seperti FPI, Muhammadiyah, NU, perkumulan tarekat, majlis dzikir, Kementerian Agama, dan sebagainya.

Secara normatif, pranata keagamaan menentukan sikap dan tindakan warganya dalam mengantisipasi dan memecahkan setiap kebutuhan keagamaannya yang bersifat mendasar. Namun, dalam realitas tidak selalu ada hubungan satu-satu antara pranata keagamaan tertentu dengan pemenuhan kebutuhan dasar keagamaan warganya, terutama bila anggotanya bersifat perorangan. Selalu ada kemungkinan baginya memperoleh jalan pemenuhan kebutuhannya itu dari saluran lain di luar, misalnya di tempatnya bekerja. Rasa tidak puas seperti itu hal biasa, misalnya di lingkungan kemasjidan RT, yang dianggapnya tidak mampu mewujudkan kebutuhan dasar keagamaannya. Walaupun demikian, tidak berarti orang tersebut kehilangan rasa keagamaannya, dan malah biasanya mempunyai pendapat sendiri tentang bagaimana seharusnya pranata tersebut berfungsi.

Secara normatif pula, pranata keagamaan mewakili prosedur-prosedur dan sikap tindakan tertentu yang harus diembannya sendiri serta untuk para waqrgaanggotanya. Sikap-sikap dan tindakan apapun dari pranata keagamaan tidak dapat dipandang sebagai taken for granted, karena semua itu menyangkut sistem 
nilai-nilai dan norma keagamaan yang sudah terlembagakan secara mapan dan bersifat kompleks. Penting sekali memahami bagaimana bekerjanya sistem nilainilai dan norma tersebut dalam pranata keagamaan. Dan terbukti, lagi-lagi, bahwa tidak selalu terdapat korespondensi satu-satu antara pranata keagamaan dengan tindakan senditi serta anggota yang ada di dalamnya. Bisa diambillkan contoh yang mudah, organisasi-organisasi keagamaan. Idealnya, sesuai dengan namanya, mereka merupakan pengejawantahan berlakuanya prodesur-prosedur dan norma-norma keagamaan yang diembannya, yang juga harus dipatuhi oleh perorangan maupun kolektif para anggotanya dalam menjalani keberagamaanya. Namun, dalam realitasnya, adakah jaminan bagi organisasi-organisasi keagamaan itu serta para pengurusnya yang tidak pernah melepaskan diri dari atribut-atribut maupun simbol-simbol keagamaan bisa terbebas dari apa yang sering disebut dengan "moral hipokrit"?

Tumbuhnya ketaatan pribadi maupun kolektif, istilah teknisnya disiplin atau takwa, yang merupakan inti dari keberagamaan, sebenarnya bukan sematamata terkait dengan persoalan normatif keagamaan saja, tetapi juga menyangkut beberapa faktor di luar agama. Sebagai penyedia nilai-nilai dan norma serta pengawas perilaku warganya, agama tidak pernah surut dalam menjalankan fungsinya, tetapi operasionalnya dalam realitas kehidupan kongkret di masyarakat bukan lagi menjadi tanggung jawab agama, melainkan seluruh pranata sosial yang ada, terutama institusi pemerintah/negara. Dalam konteks ini, kredibilitas institusi pemerintah/negara perlu dilihat, juga keseriusannya dalam menjalankan pengawasan dan penegakan hukum, apakah dapat diandalkan atau tidak? Pemerintah yang tidak lagi dipercayai rakyatnya akan sulit memperoleh kepatuhan umum, termasuk terhadap peraturan-peraturan yang dibuatnya. Ini artinya, selain faktor legitimasi, diperlukan juga aparatur pemerintah yang betwibawa dan memiliki keteladanan. Tidak terbatas hanya aparat penegak hukumnya saja, tetapi juga keseluruhannya, mulai dari level paling tinggi hingga level paling rendah, yang langsung atau tidak langsung, terkait dan berkepentingan dengan tegaknya kepatuhan bersama. Sulit diharapkan tegaknya kepatuhan publik, kalau aparatur negara tidak berwibawa 
karena tidak adanya keteladanan dari yang bersangkutan tentang apa yang dikehendaki dan diperintahkan.

Faktor berikutnya adalah berkenaan dengan konsistensi dalam penegakan aturan atau hukum. Sebab bila peraturan mudah berubah dan diubah, kewibawaan dengan sendirinya akan mudah rusak, hingga berakibat pada rusaknya kepatuhan atau ketaatan umum. Agama mengajarkan bahwa konsistensi (istiqamab) merupakan syarat agar amalan dapat mencapai hasil optimal. Dalam upaya penegakkan "tertib hukum" dan "kepastian hukum", konsistensi sangat penting. Artinya, kehendak agar masyarakat mematuhi norma-hukum tidak cukup hanya ditekankan pada kalangan masyarakat bawah saja, tetapi juga kalangan atas secara bersamaan. Di sini tidak boleh ada pengecualian dan tidak boleh juga ada faktor pemutus atau interupsi. Ambil contoh sederhana, pembiasaan dan kebiasaaan mematuhi ketentuan harus berhenti pada lampu merah di jalan dengan sendirinya akan buyar, kalau lampu merah sendiri sering mati. Masalah kelangkaan (scarcity) juga harus dihindari. Sebab kesulitan memperoleh sesuatu yang diperlukan orang banyak, akan mendorong orang untuk mengabaikan kepatuhan pada aturan. Seseorang biasanya patuh karena yakin akan memperoleh sesuatu yang dikehendaki, tanpa harus berebut dan merusak aturan. Sebaliknya, bila tidak ada keyakinan seperti itu, ia cenderung mencari-cari "jalan pintas", sehingga menjadikan ketaatan dengan sendirinya rusak. Akhirnya, faktor rasa keadilan tidak boleh diabaikan. Kepatuhan dengan sendirinya akan terwujud jika dalam masyarakat terdapat keadilan yang dapat dirasakan oleh semua. Sebaliknya, "ide-ide petlawanan" atau balelo, dengan sendirinya akan muncul bila dalam masyarakat tersimpan rasa teringkati dan diperlakukan tidak adil. Fenomena ketidakmampuan masyarakat mematuhi peraturan umum jelas berkaitan langsung dengan masalah-masalah di atas.

Bagaimana pemetintah/negara kita mengelola kepatuhan atau disiplin publik? Meminjam pendapat Gunnar Myrdall, seperti diuktip Nurcholish Madjid, pemerintah/negara kita termasuk sangat lemah dalam hal ini, sehingga dapat digolongkan ke dalam kelompok negera-negara soft etbics, karena seringnya terjadi ketidakjelasan atau kekaburan antara perilaku benat dan salah di 
masyarakat. ${ }^{19}$ Berbagai bentuk ketidaktaatan atau pelanggaran moral di masyarakat, bahkan di kalangan para pejabat/penyelenggara negara sendiri, seperti korupsi dan penyalah-gunaan kekuasaan, dianggap hal biasa. Sangat kontradiktif dengan atribut religius yang selalu disandangkan kepada masyarakat kita. Menurut kalangan agamawan, lemahnya etika-moral masyarakat-bangsa kita karena dibentuk oleh jenis pemahaman keagamaan yang bersifat parsial, misalnya yang hanya mementingkan ritus-ritus peribadatan belaka. Sejauh ini ketaatan masyarakat terhadap agama kebanyakan masih diukur dari segi formalitasnya, dalam arti kedapat-tepenuhinya ketentuan-ketentuan fiqh, bukan dari aspek moral-etika dan tindak-tanduk sehari-hari selaku orang beragama. ${ }^{20}$ Tentu saja, pola pemahaman agama masyarakat seperti ini harus segera dikoreksi dengan memberikan perluasan-petluasan dan penyegaran-penyegaran agar tercipta pola pemahaman agama baru di masyarakat yang lebih komprehensif. Namun apalah artinya semua itu, bila perilaku pemerintah/negara sendiri, terutama aparatnya, tidak menunjukkan kesungguhan dalam menangani persoalan kemerosotan moral publik. Pepatah bahwa agama raja menunjukkan agama rakyatnya tampaknya masih tetap relevan untuk dikemukakan di sini.

Jadi, jelaslah bahwa atribut religius yang selama ini dikenakan pada masyarakat kita sesungguhnya tidak menunjukkan arti substanstifnya, melainkan hanya bersifat formal atau paling banter dalam skop personal saja. Karena itu, diperlukan sedikit kecermatan dan kehati-hatian dalam penempatannya, agar tidak terjadi salah persepsi yang bisa membuat agama lebih terbebani. Seperti sudah kita lihat, masyarakat kita hidup dalam keanekaragaman nilai-nilai budaya, yang tentu saja tidak bisa diklaim seluruhnya berasal dari dan mendasarkan diri pada nilai-nilai dan norma agama. Posisi agama yang marjinal dalam konteks keseluruhan kebudayaan kita sebenarnya bisa menjadi petunjuk tentang seberapa kuat agama telah memasuki dan menuntun kehidupan masyarakat. Yang jelas, bersama-sama agama, terserap pula nilai-nilai dan norma-norma dari

19 Nurcholish Madjid, "Aktualisasi Ajaran Ahlussunnah Wal Jama'ah" dalam M. Dawam Rahardjo, Islam Indonesia Menatap Masa Depan, (Jakarta: P3M, 1984) hal. 74.

${ }^{20}$ Harun Nasution, Islam Rasional, (Bandung: Mizan, 1995), hal. 60. 
luar, apakah bersifat nasional maupun kedaerahan, yang turut membentuk alam pikiran dan perilaku budaya masyarakat kita. Sebagai modal budaya, bisa jadi corak keberagamaan masyarakat kita yang lebih menonjolkan aspek-aspek formalisme-personalnya daripada aspek-aspek substantif-sosialnya, justru merupakan "produk akhir" dari proses dialektika sejarah keagamaan kita selama bergumul dan bernegosiasi dengan realitas. Katakanlah sebuah pilihan, daripada tidak diperoleh isi pokok dari hakekat keberagamaan, bungkus luarnya juga boleh. Atau, barangkali semua ini merupakan bukti "kemenangan" yang telah diperjuangkan selama beberapa abad oleh golongan syariat atas golongan tasawuf dalam Islam, yang merupakan agama mayoritas di negara ini.

Hidup berkeadaban pada dasarnya merupakan tujuan hakiki dari keberagamaan manusia. Oleh karena itu, selalu ada upaya untuk mewujudkannya, melalui proses pewarisan sosial, yang disebut pendidikan. Hanya saja, proses dan hasilnya.tidak selalu mulus dan sesuai dengan yang dicita-citakan, karena adanya unsur-unsur lain yang turut bermain di dalamnya. Tugas utama agama pada masyarakat sebatas memberi petunjuk dalam bentuk nilai-nilai dan norma yang harus diikuti serta memberikan kontrol yang bersifat rohani, tetapi bagaimana operasionalnya dalam realitas sangat tergantung pada sejauh mana kesediaan mereka dan pranata-pranata sosial yang ada, terutama pemerintah/negara, menerima dan tunduk takluk di bawahnya demi ketinggian martabat manusia sendiri. Singkatnya, diperlukan sinergisitas yang konstruktif di antara berbagai unsur masyarakat yang ada dalam pembumian agama. Tanpa itu, apa yang secara normatif diajarkan agama akan tetap menjadi hiasan langit, yang tidak pernah operasional dalam kehidupan kongkret di masyarakat. Dan kondisi inilah yang sejauh ini terjadi di masyarakat kita.

\section{Penutup}

Operasionalisasi nilai-nilai dan norma agama dalam hidup bermasyarakat secara berkeadaban berada dalam hubungan kait-mengkait yang rumit antara agama sendiri di satu pihak dengan kebudayaan dalam mana individu dan masyarakat berada dan hidup di pihak lain. Metosotnya perilaku publik dari bangsa kita yang dikenal religius tidak bisa sepenuhnya ditimpakan kepada 
agama dan institusinya yang dianggap telah gagal dalam mengemban misi sucinya membawa perbaikan hidup masyarakat ke arah yang lebih baik. Posisi agama yang marjinal dalam struktur kebudayaan kita bisa jadi menjadi salah satu penyebab utama kegagalan tersebut, karena menjadikannya tidak mampu memainkan fungsi sosialnya secara maksimal. Tetapi juga tidak fair kalau hanya agama, termasuk di dalamnya pranatanya, yang harus menanggung beban itu, karena di luar agama sesungguhnya masih terdapat unsur-unsur penentu lainnya yang memegangh peranan, terutama negara. Dalam posisi "hegemonic", negara beserta aparatanya seharusnya bisa mengambil peran lebih besar dalam usaha pembinaan moral masyarakat dan penegakan tertib sosial dan tertib hukum. Rendahnya kepatuhan publik di masyarakat kita sekarang ini sesungguhnya merupakan cerminan riil dari sikap dan perilaku negara yang tidak pernah sungguh-sungguh dalam mentaati berbagai ketentuan dari peraturan yang dibuatnya sendiri.

\section{DAFTAR PUSTAKA}

Ali, A. Mukti. 1981. Beberapa Persoalan Agama Dewasa Ini, Jakarta: Rajawali Press. Abdullah, Taufik. 1996. Islam dan Masyarakat Pantulan Sejarab Indonesia, Jakarta, LP3ES.

Bertens, K., 1997. Etika, Jakarta, Gramedia.

Cannon, Dale. 2002. Enam Cara Beragama, Penerjemah Djam'annuri, Jakarta, Dipertais Depag RI.

Effendy, Bakhtiar. 1999. 'Wawasan Al-Qur'an tentang Masyarakat Madani Menuju Terbentuknya Negara-Bangsa yang Modern", Paramadina, Vol. I No. 2.

Koentjaraningrat. 1993. Kebudayaan Mentalitas dan Pembangunan, Jakarta, Gramedia.

Madjid, Nurcholish. 2000. Masyarakat Religius Membumikan Nilai-Nilai Islam dalam Kehidupan Masyarakat, Jakarta, Paramadina. 
------, 1984."Aktualisasi Ajaran Ahlussunnah Wal Jama’ah" dalam M. Dawam Rahardjo, Islam Indonesia Menatap Masa Depan, Jakarta, P3M.

Nasution ,Harun. 1995. Islam Rasional, Bandung, Mizan. , 1985.Islam Ditinjau dari Berbagai Aspeknya, Jakarta, UI Press.

Suparlan, Parsudi. 1992/1993. "Pendidikan Budaya Manusia Indonesia", dalam Sudjangi (ed.) Kajian Agama dan Maryarakat, Jakarta, Balitbang Agama Depag RI, Jilid III.

-------, 1998. "Penelitian Agama Islam: Tunjauan Disiplin Antropologi", dalam Mastuhu dan Deden Ridwan, Tradisi Baru Penelitian Agama Islam Tinjauan Antar Disiplin, Bandung, Nuansa.

-.._. 1986. "Kebudayaan dan Pembangunan", IKA, No. 11 Tahun XIV. Tibi, Bassam. 1999. Islam Kebudayaan dan Perubaban Sosial, Yogyakarta, Tiara Wacana. 
558 Millab Vol. XI, No. 2, Februari 2012 